\title{
Pathways Independent of Contamination May Produce Burn Wound Infections
}

\author{
Alen J Salerian MD* \\ Organisation Modern Psychiatry, Greece
}



*Corresponding author: Alen J Salerian MD, Organisation Modern Psychiatry, Zaimi street, paleo falero, Athens 17562, Greece

Abstract

Background: A plethora of evidence suggest pathways independent of contamination may produce microbial growth and infections.

Objective: To prove that pathways independent of contamination may produce burn wound infections.

Methods: We searched the keywords burn wound infections in Google scholar and pub med for articles and their references published in English from 2000 to 2017 . We then applied the probability theory to calculate the probability of pathways independent of contamination to produce burn wound infections.

Results: Pathways independent of contamination may produce burn wound infections. The probability of certainty of this observation is 99.9998\%.

Conclusion: Pathways independent of contamination may produce burn wound infections.

Keywords: Germ Theory; Infections; Gastric Ulcers; Duodenal Ulcers; Burn Wounds Infections

\section{Introduction}

Scientific observations suggest pathways independent of contamination may produce infections [1,2]. For instance, unicellular organisms (prokaryota) including bacteria transformed from lifeless matter 3.5 billion years ago [3-5]. Murchison meteorite contain organic compounds consistent with the existence of vital substances necessary for life in universe [6] Organic compounds were produced by artificial methods [7].

\section{Objective}

To prove that pathways independent of contamination may produce burn wound infections.

\section{Methods}

I searched the keywords burn wound infections in Google scholar and Pub Med for articles and their references published in English from 2000 to 2017. We then applied the probability theory to calculate the probability of pathways independent of contamination to produce burn wound infections.

\section{Results}

\section{Evidence Consistent with Pathways Independent of Contamination Cause Infections}

Microorganisms transform to other microorganisms [8]. Human cells transform to different cells $[9,10]$. A lifeless protein transforms to an infectious prion [11]. Tinea versicolor is caused by microorganisms that are part of normal flora [12,13]. Any one of the three host properties (genetics, medications, skin conditions) determines whether someone develops tinea versicolor $[14,15]$ and this observation is consistent with a cell mediated model in which transformation can be ascribed.

Also, studies indicate tinea versicolor is not contagious and it's not possible to infect a rabbit or human host with tinea versicolor by inoculating pityrosporum orbiculare or pityrosporum ovale without occlusion $[14,15]$. Together, these results describe a cell mediated model, in which transformation can be ascribed. H. pylori are part of normal gastric flora and result either from contamination or transformation. Epidemiological studies and clinical observations show no evidence of host to host contamination in h.pylori infections [16]. This observation is also consistent with a cell mediated model in which transformation can be ascribed.

Sterile burn wounds treated vigorously with anti-microbial substances always develop infections by very rare pathogens $[17,18]$. This suggests a cell mediated model in which transformation can be ascribed. The emphasis here is the same as h.pylori and tinea versicolor that burn infections are also cell mediated diseases consistent with transformation. A plethora of evidence suggest normal flora may come from trans formation of human cells 
consistent with the observations that the amniotic fluid, placenta, milk of healthy neonates are not sterile [19-22].

\section{Mathematical Evidence: The Probability That Burn Infections May Result from Transformation of Human Tissue}

The probability of a physically possible observation to be correct exponentially increases by each supporting evidence and can be expressed as an equation: $\mathrm{C}=100-1 / 2 \mathrm{n}$ ("C"representing the percent probability of certainty and " $n$ "representing the number of diverse evidence consistent with the observation).

This equation is based upon the premise that each supporting evidence or observation is a hypotheses -a logical inference from observing facts from which consequences may be deduced -with a $\% 50$ chance of being correct and therefore the final outcome would be the same as the probability of random occurrence in flipping a coin. Hence it would be like "heads "coming up a consecutive number "n"of times. For instance, the probability of "heads" coming up 3 consecutive times is $1 / 23$ or $1 / 8$ or $11 \%, 10$ consecutive times is $1 / 210$ or $\% 0.09$.

Of crucial significance, consistent with the framework of flipping a coin, potential flaws of statistical analysis - randomness and bias- have no effect on the accuracy of final outcome. As long as it is fair play without tricks it does not matter who flips the coin.

The probability that burn wound infections may result from transformation of human tissue is \% 99.9996:

a) Organic compounds were produced by artificial methods [7].

b) A lifeless protein transforms to an infectious prion [11].

c) Microorganisms transform to other microorganisms $[8,9]$.

d) Human cells transform to different cells [10].

e) Lifeless organic matter of earth transformed to microbes [3].

f) Murchison meteorite contain organic compounds consistent with the existence of vital substances necessary for life in universe [6].

g) Amniotic fluid is not sterile [19-22].

h) Meconium is not sterile [20-22].

i) Human milk is not sterile [20-22].

j) Placenta is not sterile [20-22].

k) Tinea versicolor infections are not contagious [12,13].

l) Inoculation of tinea versicolor pathogens do not cause infections without occlusion $[14,15]$.

m) Epidemiological data suggest $\mathrm{H}$ pylori-gastric ulcer infections are not transmitted from host to host [16]. n) Bacteria exist in extraordinarily remote locations on earth [23].

o) Theory of evolution [24].

p) Sterile burn wounds vigorously treated with antibiotics in burn units with excellent infection prevention almost always develop microbial growth and infections $[17,18]$.

q) Sterile burn wounds vigorously treated with antibiotics in burn units with excellent infection often develop infections by Pseudomonas aeruginosa PA01, an opportunistic pathogen with morphological features (large genome size, greater functional complexity and the younger evolutionary age) very different than normal bacteria [17-19,25].

\section{Discussion}

Although, the precise mechanism and pathways of transformation remain unknown, we can state that pathways independent of contamination may generate burn wound infections and the probability of this observation to be correct is $99.9996 \%$.

This discovery may introduce novel treatments for opportunistic infections especially those associated with burns and major trauma. It may improve our understanding of inflammatory disorders and discovering yet unknown environmental influences (sudden temperature changes, exposure to cold) in the pathogenesis of common or unrecognized infections.

\section{References}

1. Salerian AJ (2017) Human body may produce bacteria. Medical Hypotheses 103: 131-132.

2. Salerian AJ (2018) Was Pasteur Wrong? Human Cells may Generate Bacteria. Biomed J Sci \&Tech Res 4(5).

3. Schopf JW (2006) Fossil evidence of Arcaean Life. philosophical transactions of the Royal Society biological sciences 361(1470).

4. Cavalier-Smith T (2006) Cell evolution and Earth history: Stasis and revolution. Philosophical transactions Royal Society in London biological sciences, UK 361(1470): 969-1006.

5. Altermann W, Kazmieczak J (2003) Archean Micro fossils: A reappraisal for early life on earth. Researching microbiology 154(9): 611-617.

6. Engel MH, Mako SA (1997) Isotopic evidence for extraterrestrial amino acids in the Murchison Meteorite. Nature 389(6648): 265-268.

7. Lazcano A, Bada JL (2003) Orig Life Evol Biosph 33: 235

8. Rosenow EC (1914) Test mutations within the streptococcus enamel proper school. Journal of Infectious Disorders 14(1): 1-32.

9. Bracco RM, Krauss MR, Roe AS, MacLeod CM (1957) Transformation Reactions Between Pneumococcus and Three Strains of Streptococci. J Exp Med 106(2): 247-259.

10. Krause DS, Thiese ND, Collector ML (2001) Multi-Organ, Multi-Lineage Engraftment by a Single Bone Marrow-Derived Stem Cell. Cell 105(3): 369-377.

11. Brown P, Will RG, Bradley R, Asher DM, Detwiler L (2001) Bovine spongiform encephalopathy and variant Creutzfeldt- Jacob disease: Background evolution and current concerns. Emerging Infectious Diseases 7(1): 6-16. 
12. Hafez Ma, El-Shamy SB (1985) Genetic Susceptibility in Pityriasis versicolor. Dermatologica 171(2): 86-88.

13. Burke R (1961) Tinea Versicolor: Susceptibility factors in experimental infection in human beings. Journal of investigative dermatology 36: 389402.

14. Faergemann J, Fredricksson $T$ (1981) Experimental infections in rabbits and humans with Pityrosprum orbiculare and P.ovale. Journal of Investigative Dermatology 77(3): 314-318.

15. Faergemann J, Aly R, Wilson DR, Maibach HI (1983) Skin occlusion: Effect on Pityrosprum orbiculare, skinP-C02, ph, trans epidermal water loss, and water content. Archives of dermatological research. 275(6): 383-387.

16. Najm WI (2011) Peptic ulcer disorder. Primary care 38(3): 383-394.

17. Macedo JLS, Santos JB (2005) Bacterial and fungal colonization of burn wounds. Mem Inst Oswaldo Cruz, 100(5): 535-539.

18. Kaur H, Bhat J, Anvikar AR, Rao S, Gadge V (2006) Bacterial profile of blood and burn wound infections in burn patients. Burns 34: 89-95.

19. Stover CK, Pham XQ Olson MV (2000) Complete genome sequence of Pseudomonas aeruginosa PA01, an opportunistic pathogen. Nature 406: 959-964.

ISSN: 2574-1241

DOI: 10.26717/BJSTR.2018.08.001701

Alen J Salerian MD. Biomed J Sci \& Tech Res

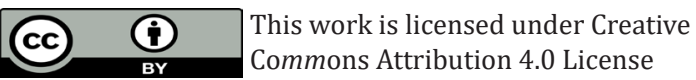

Submission Link: https://biomedres.us/submit-manuscript.php
20. Jimenez E, Marin ML, Matin R, Odriozola J, M Olivares M, et al. (2008) Is fetal meconium sterile? Research in Microbiology 159(3): 187-189.

21. Ardissone AN, DeLa Cruz D, Davis- Richardson AG, Rechigi KT (2014) Meconium microbiome analysis identifies bacteria correlated with premature birth. PLOS ONE 9(6): e101399.

22. Cabrera-Rubio R, Collado MC, Latinen K, Salminnen S, Isolauri E, et al. (2012) The human milk microbiome changes over lactation and is shaped by maternal weights mode of delivery. The American Journal of clinical nutrition 96(3): 544-551.

23. Martin R, Langa S, Reviriego C, Jimenez E, Marin ML, et al. (2003) Milk is a source of lactic acid bacteria for the infant gut. The journal of pediatrics 143(6): 754-758.

24. Dib JR, Weiss A, Neumann A, Ordonez O, Estevez M, et al. (2009) Isolation of bacteria from remote high-altitude Andean Lakes Able to grow in the presence of antibiotics. Recent patents ion Anti-infective drug discovery 4(1): 66-76.

25. Darwin C, Barlow N (1887) The autobiography of Charles Darwin. New York: Norton, WW Company Inc, USA.

$\begin{array}{ll}\text { BIOMEDICAL } & \text { Assets of Publishing with us } \\ \text { RESEARCHES } & \text { Global archiving of articles } \\ \text { - Immediate, unrestricted online access }\end{array}$

